PENELITIAN

\title{
PENGARUH TEHNIK RELAKSASI GUIDE IMAGERY TERHADAP TINGKAT KECEMASAN PASIEN PREOPERASI KATARAK
}

\author{
Budi Antoro*, Gustop Amatiria** \\ *Dosen Prodi Keperawatan STIKes Mitra Lampung \\ **Dosen Jurusan Keperawatan Poltekkes Tanjungkarang \\ e-mail: budiantoro@umitra.ac.id
}

\begin{abstract}
Jumlah penderita katarak di dunia tahun 2013 sebesar 17 juta orang. Prevalensi katarak di Indonesia tahun 2013 adalah 1,8 \%, di Provinsi Lampung prevalensi katarak adalah 1,5\%. Penatalaksanaan yang sering dilakukan pada katarak adalah dengan pembedahan. Di Indonesia, sekitar $80 \%$ dari pasien yang akan menjalani pembedahan melaporkan mengalami kecemasan. Teknik relaksasi yang biasanya digunakan adalah teknik relaksasi dengan imajinasi terbimbing (guided imagery). Tindakan operasi katarak di Rumah Sakit Mata Permana Sari meningkat jumlahnya dari tahun 2015 sebanyak 725 orang menjadi 952 orang pada tahun 2016. Tujuan penelitian ini adalah mengetahui pengaruh teknik relaksasi guide imagery dengan teknik relaksasi nafas dalam terhadap tingkat kecemasan pasien preoperasi katarak. Rancangan penelitian ini adalah pretest-postest with control group design, jenis penelitian kuantitatif. Populasi dalam penelitian ini adalah seluruh pasien preoperasi katarak di RS. Permana Sari Bandar Lampung, dengan sampel sebanyak 42 responden. Uji hipotesis digunakan analisis uji T (Dependen Sample T-Test). Hasil penelitian diperoleh ada pengaruh teknik relaksasi guide imagery dalam penurunan tingkat kecemasan $(p$ value $=0,000)$. Saran bagi tenaga kesehatan untuk dapat menerapkan teknik relaksasi guide imagery dalam asuhan keperawatan untuk menurunkan tingkat kecemasan pasien pre operasi katarak.
\end{abstract}

\section{Kata kunci : Guided Imagery, Kecemasan, Preoperasi Katarak}

\section{LATAR BELAKANG}

Kesehatan mata sangatlah penting karena penglihatan tidak dapat digantikan dengan apapun, maka mata memerlukan perawatan yang baik. Kebutaan yang diakibatkan karena katarak merupakan masalah kesehatan secara global yang harus segera ditangani, karena mengabaikan masalah mata dan penglihatan dapat mengakibatkan kebutaan dan kehilangan fungsi mata. Penyakit umum pada mata dapat digolongkan dalam beberapa kelompok, salah satu penyebab dari kebutaan di seluruh dunia adalah katarak. Katarak adalah dimana keadaan suatu lensa mata yang pada awalnya jernih menjadi keruh (Sidarta, dalam Wahyuningtyas 2016).

Katarak yang merupakan penyebab utama berkurangnya penglihatan di dunia diperkirakan jumlah penderita kebutaan katarak di dunia saat ini sebesar 17 juta orang dan akan meningkat menjadi 40 juta pada tahun 2020. Sedangkan di Indonesia jumlah penderita katarak mencapai 2,4 juta orang. Pertambahan penderita katarak setiap tahun sekitar 240 ribu. Pertumbuhan penderitanya sudah melebihi angka $1 \%$ dari jumlah penduduk. Berdasarkan data Riset Kesehatan dasar (Riskesdas) Tahun 2013, prevalensi katarak semua umur tahun 2013 adalah 1,8 persen, sedangkan di Provinsi Lampung prevalensi katarak adalah 1,5\% (Kemenkes RI, 2013).

Penatalaksanaan yang sering dilakukan pada katarak adalah dengan pembedahan. Metode operasi yang umum dipilih untuk katarak adalah meninggalkan bagian posterior kapsul lensa sehingga dikenal sebagai ekstraksi katarak ekstrakapsular. Penanaman lensa intraokular merupakan bagian dari prosedur ini (Vaughan \& Asbury, 2007). Pada pelaksanaan metode ini, pasien praoperatif dapat mengalami berbagai ketakutan. Takut terhadap anastesi, takut terhadap nyeri atau kematian, takut tentang ketidak tahuan atau takut tentang deformitas atau ancaman terhadap citra 
tubuh dapat menyebabkan ketidaktenangan atau ansietas (Smeltzer \& Bare, 2007).

Kecemasan (ansietas) merupakan reaksi normal terhadap stres dan ancaman bahaya. Kecemasan merupakan reaksi emosional terhadap persepsi adanya bahaya, baik yang nyata ataupun yang dibayangkan. Kecemasan merupakan reaksi yang umum terhadap penyakit karena penyakit dirasakan sebagai suatu ancaman umum terhadap kehidupan, kesehatan, dan keutuhan tubuh (Smeltzer $\&$ Bare, 2007).

Data di Indonesia, sekitar $80 \%$ dari pasien yang akan menjalani pembedahan melaporkan mengalami kecemasan. Kecemasan dapat berakibat pada peningkatan tekanan darah ataupun gula darah pasien operasi. Persiapan yang baik selama periode operasi membantu menurunkan resiko operasi dan meningkatkan pemulihan pasca bedah (Sobur, 2008).

Persiapan prabedah penting sekali untuk mengurangi faktor resiko, karena hasil akhir dari suatu pembedahan sangat bergantung pada penilaian keadaan penderita. Secara mental, penderita harus dipersiapkan untuk menghadapi pembedahan, karena selalu ada rasa cemas atau takut terhadap penyuntikan, nyeri luka, bahkan terhadap kemungkinan cacat atau mati (Sobur, 2008).

Hasil riset tentang intervensi keperawatan terhadap stres dan kecemasan yang dilakukan sejak 1980-1990, Snyder dan Egan menemukan teknik relaksasi sebagai metode utama untuk menghilangkan stresor. Tujuan latihan relaksasi adalah untuk menghasilkan respon yang dapat memerangi respon terhadap stresor. Teknik relaksasi yang biasanya digunakan adalah teknik relaksasi dengan imajinasi terbimbing (guided imagery) (Brunner \& Suddarth, 2007).

Teknik relaksasi imajinasi terbimbing (guided imagery) merupakan penggunaan imajinasi dengan sengaja untuk memperoleh relaksasi dan menjauhkan dari sensasi yang tidak diinginkan (Brunner \& Suddarth, 2007). Rumah Sakit Mata Permana Sari merupakan satu-satunya rumah sakit di Provinsi Lampung yang di khususkan bagi pasien dengan gangguan kesehatan mata. Berdasarkan data yang diperoleh dari rekam medik, jumlah pasien dengan tindakan operasi katarak meningkat jumlahnya dari tahun 2015 sebanyak 425 orang menjadi 552 orang pada tahun 2016. Berdasarkan fenomena yang terjadi pada pasien preoperasi katarak sebagian besar mengalami kecemasan. Hasil presurvey dengan melakukan wawancara terhadap 10 orang pasien preoperasi katarak, terdapat 8 orang $(80 \%)$ mengalami gejala kecemasan seperti jantung berdebar, gelisah, perasaan tegang, dan sering berkemih, sedangkan 2 orang (20\%) tidak merasakan gejala kecemasan tersebut saat menghadapi rencana operasi. Kemudian berdasarkan hasil wawancara kepada perawat di ruangan tersebut, bahwa tidak pernah dilakukan penatalaksanaan kecemasan dengan tindakan nonfarmakologi salah satunya adalah teknik relaksasi guide imagery. Penelitin ini bertujuan untuk mengetahui pengaruh teknik relaksasi guide imagery terhadap tingkat kecemasan pasien preoperasi katarak.

\section{METODE}

Rancangan penelitian ini adalah pretest-postest with control group design. Jenis penelitian yang digunakan adalah penelitian kuantitatif. Penelitian telah dilaksanakan pada bulan 17 Juni s.d 17 Juli 2017 di Kamar Tunggu RS. Permana Sari Bandar Lampung. Populasi dalam penelitian ini adalah seluruh pasien preoperasi katarak di RS. Permana Sari Bandar Lampung, dengan rata-rata 46 orang/ bulan, dalam penelitian ini sampel dibagi menjadi menjadi dua kelompok yaitu untuk kelompok intervensi sebanyak 21 responden, dan untuk kelompok kontrol sebanyak 21 orang.

Teknik pengambilan sampel dalam penelitian ini menggunakan accidental sampling. Variabel penelitian yang digunakan dalam penelitian ini yaitu variabel bebas (independent) yaitu 
pelaksanaan teknik relaksasi guided imagery. Serta variabel terikat (dependent) yaitu tingkat kecemasan. Alat pengumpul data pada penelitian ini adalah dengan menggunakan lembar observasi berdasarkan hasil cek list terhadap 20 soal. Penilaian yang dilakukan untuk menilai tingkat kecemasan dengan rentang skor 020.

Analisis data terdiri dari analisa univariat untuk melihat distribusi frekuensi variabel dependent dan variabel independent yang akan menghasilkan mean, median dan simpangan baku dan persentasi di setiap variabel penelitian. Kemudian analisa bivariat dilakukan untuk melihat pengaruh teknik relaksasi guide imagery terhadap tingkat kecemasan pasien preoperasi katarak di RS. Permana Sari Bandar Lampung Tahun 2017. Rumus yang digunakan analisis uji $\mathrm{T}$ (Dependen Sample T-Test).

\section{HASIL}

\section{Analisis Univariat}

Tabel 1: Rata-Rata Tingkat Kecemasan sebelum diberikan tehnik relaksasi Guided Imagery pada Pasien Preoperasi Katarak

\begin{tabular}{lcccc}
\hline Variabel & Mean & Median & SD & Min-Max \\
\hline Intervensi & 13,48 & 14 & 2,482 & $9-17$ \\
\hline Kontrol & 13,05 & 14 & 2,711 & $8-17$ \\
\hline
\end{tabular}

Berdasarkan tabel di atas dapat diketahui bahwa tingkat kecemasan pada pasien pre-operasi katarak sebelum dilakukan teknik relaksasi guided imagery memiliki skor rata-rata 13,48 , dengan nilai minimum 9 dan nilai maksimum 17. Kemudian tingkat kecemasan pada pasien kontrol memiliki skor rata-rata 13,05, dengan nilai minimum 8 dan nilai maksimum 17.
Tabel 2: Rata-Rata Tingkat Kecemasan sesudah diberikan tehnik relaksasi Guided Imagery pada Pasien Preoperasi Katarak

\begin{tabular}{lcccc}
\hline Variabel & \multicolumn{2}{c}{ Mean Median } & SD & Min-Max \\
\hline Intervensi & 8,57 & 8 & 2,181 & $3-13$ \\
\hline Kontrol & 8,62 & 9 & 2,636 & $4-13$ \\
\hline
\end{tabular}

Berdasarkan tabel di atas dapat diketahui bahwa tingkat kecemasan pada pasien mengalami penurunan setelah diberi intervensi teknik guided imagery menjadi 8,57 , dengan nilai minimum 3 dan nilai maksimum 13. Kemudian pada kelompok kontrol tingkat kecemasan pasien mengalami penurunan menjadi 8,62 dengan nilai minimum 4 dan nilai maksimum 13 .

\section{Analisis Bivariat}

Tabel 3: Hasil Uji Paired Sample t-Test Teknik Guided Imagery Terhadap Penurunan Tingkat Kecemasan Pada Pasien Pre-Operasi Katarak

\begin{tabular}{lccccc}
\hline \multicolumn{1}{c}{ Variabel } & Mean & SD & SE & $\begin{array}{c}p- \\
\text { value }\end{array}$ & $\mathrm{n}$ \\
\hline $\begin{array}{l}\text { Tehnik Relaksasi } \\
\text { guided imagery }\end{array}$ & 4,905 & 2,119 & 0,462 & 0,000 & 21 \\
\hline
\end{tabular}

Berdasarkan tabel di atas dapat diketahui bahwa hasil uji paired sample ttest pada hasil skore tingkat kecemasan pada kelompok intervensi dan kontrol diperoleh nilai signifikasi $p$-value $=0,000$ ( $p$-value $<\alpha(0,05)$, maka dapat disimpulkan bahwa terdapat pengaruh teknik guided imagery dalam penurunan tingkat kecemasan pada pasien pre-operasi di RS. Permana Sari Bandar Lampung Tahun 2017.

\section{PEMBAHASAN}

Berdasarkan hasil penelitian diperoleh bahwa tingkat kecemasan pada pasien pre-operasi katarak sebelum dilakukan teknik relaksasi guided imagery memiliki skor rata-rata 13,48 , dengan nilai minimum 9 dan nilai maksimum 17 . Kemudian tingkat kecemasan pada pasien 
pre-operasi katarak pada kelompok kontrol memiliki skor rata-rata 13,05 , dengan nilai minimum 8 dan nilai maksimum 17.

Sedangkan tingkat kecemasan pada pasien mengalami penurunan setelah diberi intervensi teknik guided imagery menjadi 8,57, dengan nilai minimum 3 dan nilai maksimum 13. Kemudian pada kelompok kontrol menjadi 8,62 dengan nilai minimum 4 dan nilai maksimum 13 .

Penelitian ini sejalan dengan teori yang dikemukakan oleh Smeltzer \& Bare, (2007), bahwa kecemasan (ansietas) merupakan reaksi normal terhadap stres dan ancaman bahaya. Kecemasan merupakan reaksi emosional terhadap persepsi adanya bahaya, baik yang nyata ataupun yang dibayangkan. Kecemasan merupakan reaksi yang umum terhadap penyakit karena penyakit dirasakan sebagai suatu ancaman umum terhadap kehidupan, kesehatan, dan keutuhan tubuh. Selain itu, menurut Stuart \& Sundeen (2009), ansietas merupakan kekhawatiran yang tidak jelas dan menyebar, yang berkaitan dengan perasaan tidak pasti dan tidak berdaya. Keadaan emosi ini tidak memiliki objek yang spesifik.

Hasil penelitian ini sejalan dengan penelitian yang dilakukan oleh Aprianto (2015), tentang efektifitas teknik relaksasi imajinasi terbimbing dan nafas dalam terhadap penurunan kecemasan pada pasien pre operasi, diperoleh hasil pada terapi imajinasi terbimbing diperoleh ratarata skor kecemasan sebelum tindakan imajinasi terbimbing adalah 43,97 dan rata-rata skor kecemasan sebelum pada kelompok kontrol adalah 41,70.

Menurut peneliti, hasil pretest pada tingkat kecemasan responden, yaitu pasien pre operasi katarak, merupakan tingkat kecemasan yang secara umum dialami ketika seseorang akan menghadapi suatu stresor yaitu tindakan operasi. Dimana halhal yang menjadi sebab berdasarkan wawancara kepada responden antara lain takut pembiusan, takut nyeri, takut operasi gagal serta takut biaya yang akan dikeluarkan. Semua itu akan menimbulkan kondisi cemas pada pasien.
Penelitian ini juga sejalan dengan teori yang dikemukakan oleh Smeltzer \& Bare (2007), guided Imagery merupakan teknik relaksasi menggunakan imajinasi seseorang dalam suatu cara yang dirancang secara khusus untuk mencapai efek positif tertentu. guided imagery yang sederhana adalah penggunaan imajinasi dengan sengaja untuk memperoleh relaksasi dan/ atau menjauhkan diri dari sensasi yang tidak diinginkan. Hasil penelitian ini sejalan dengan penelitian yang dilakukan oleh Aprianto (2015), tentang efektifitas teknik relaksasi imajinasi terbimbing dan nafas dalam terhadap penurunan kecemasan pada pasien pre operasi, diperoleh hasil pada terapi imajinasi terbimbing diperoleh selisih sebelum dan sesudah sebesar 9,07 dan pada kelompok kontrol terdapat selisih sebelum dan sesudah sebesar 8,3.

Menurut peneliti, tingkat kecemasan pada pasien mengalami penurunan setelah diberi intervensi teknik guided imagery dikarenakan kondisi kecemasan pada pasien yang akan menjalani operasi akan menimbulkan masalah fisik atau psikologis. Masalah psikologis dapat berupa perasaan cemas, tegang ataupun takut yang menimbulkan ketidak nyamanan pada diri pasien. Dengan teknik relaksasi guided imagery diharapkan dapat menimbulkan perasaan nyaman bagi pasien sehingga mengurangi kecemasan.

Berdasarkan hasil penelitian dan uji paired sample t-test pada skore tingkat kecemasan pada kelompok intervensi dan kontrol diperoleh nilai signifikasi $p$ value $=0,000$ ( $p$-value $<\alpha(0,05)$, maka dapat disimpulkan bahwa terdapat pengaruh teknik guided imagery dalam penurunan tingkat kecemasan pada pasien pre-operasi katarak di RS. Permana Sari Bandar Lampung Tahun 2017.

Hasil penelitian ini sejalan dengan teori yang dikemukakan oleh Guyton dan Hall (2008), bahwa guided imagery merupakan suatu teknik yang menuntut seseorang untuk membentuk sebuah bayangan/imajinasi tentang hal-hal yang disukai. Hal-hal yang disukai dianggap sebagai sinyal penting oleh hipokampus 
sehingga diproses menjadi memori. Dengan membayangkan hal-hal yang disukai maka homon 'kebahagiaan' (betaendorfin) akan berproduksi. Beta-endorfin kemudian akan berperan dalam menghambat ACTH (Adrenocorticotropic Hormone) yang diproduksi oleh hipofisis dan akan menghambat diproduksinya kortison dan berbagai hormon stres lainnya sehingga akan mengurangi stres atau kecemasan.

Hasil penelitian ini sejalan dengan penelitian yang dilakukan oleh Aprianto (2015), tentang efektifitas teknik relaksasi imajinasi terbimbing dan nafas dalam terhadap penurunan kecemasan pada pasien pre operasi, diperoleh hasil ada pengaruh teknik relaksasi imajinasi terbimbing terhadap penurunan kecemasan pasien pre operasi di RSUD RA Kartini Jepara dengan ( $p$-value $=0,000)$.

Menurut peneliti, pengaruh teknik guided imagery dalam penurunan tingkat kecemasan pada pasien pre-operasi katarak disebabkan karena teknik relaksasi dengan guided imagery akan memberikan relaksasi terhadap perasaan cemas dan takut yang dirasakan responden pada saat pre-operasi. Guided imagery akan meningkatkan perasaan tenang dan damai serta memberikan kenyamanan bagi fikiran. Hal tersebut akan menciptakan kesan-kesan yang dapat membawa ketenangan fikiran serta membuang fikiran negatif atau pikiran menyimpang yang ditimbulkan akibat rencana operasi. Dengan menerapkan teknik relaksasi dengan guided imagery secara benar maka perasaan seseorang akan merasa tenang sehingga dapat menurunkan tingkat kecemasan pada pasien pre-operasi.

\section{KESIMPULAN}

Berdasarkan hasil penelitian
diperoleh hasil penelitian tingkat
kecemasan pada pasien pre-operasi katarak
sebelum dilakukan teknik relaksasi guide
imagery memiliki skor rata-rata 13,48 , dengan nilai minimum 9 dan nilai maksimum 17. Sedangkan tingkat kecemasan pada pasien mengalami penurunan setelah diberi intervensi teknik guide imagery menjadi 8,57 , dengan nilai minimum 3 dan nilai maksimum 13. Hasil analisa bivariat dapat disimpulkan Ada Pengaruh teknik guide imagery terhadap penurunan tingkat kecemasan pada pasien pre-operasi di RS. Permana Sari Bandar Lampung Tahun 2017 ( $p$-value =0,000).

Dari hasil penelitian disarankan untuk dapat menjadikan penelitian ini sbagai referensi bagi penelitian selanjutnya untuk melakukan penelitian yang berkaitan dengan teknik relaksasi guide imagery untuk meningkatkan hasil penelitian dengan memperluas subjek penelitian atau dengan mengambil variabel yang belum diteliti dalam penelitian ini.

\section{DAFTAR PUSTAKA}

Aprianto, Dino. 2015. Efektifitas Teknik Relaksasi Imajinasi Terbimbing Dan Nafas Dalam Terhadap Penurunan Kecemasan Pada Pasien Pre Operasi. Skripsi. Tidak diterbitkan. Guyton,AC. Hall, JE. 2008. Buku Ajar Fisiologi Kedokteran .Jakarta: EGC.

Kemenkes RI. 2013. Riset Kesehatan Dasar Tahun 2013. Jakarta.

Smeltzer \& Bare. 2007. Keperawatan Medikal Bedah vol 1. Jakarta: EGC.

Sobur, Alex. 2008. Psikologi Umum. Bandung: Pustaka Setia.

Stuart \& Sundeen. 2009. Buku Saku Keperawatan Jiwa. Jakarta: EGC.

Vaughan \& Asbury. 2007. Oftalmologi Umum. Jakarta: EGC.

Wahyuningtyas. 2016. Hubungan Tingkat Pengetahuan Tindakan

Phacoemulsifikasi dengan

Kecemasan Pada Pasien Katarak di Rumah Sakit Mata Solo. Skripsi. Tidak diterbitkan. 